Int. J. Electrochem. Sci., 13 (2018) 10911 - 10933

International Journal of

ELECTROCHEMICAL

SCIENCE

www.electrochemsci.org

\title{
The Non-Adiabatic Model of Air-Breathing Micro Direct Methanol Fuel Cells
}

\author{
Luwen Wang, Yong Huang, Zhaoxia Yuan, Yumin Xu and Gaofeng Wang ${ }^{*}$ \\ College of Electronic and Information Engineering, Hangzhou Dianzi University, Hangzhou 310018, \\ China; \\ *E-mail: gaofeng@hdu.edu.cn
}

doi: $10.20964 / 2018.11 .82$

Received: 8 June 2018 / Accepted: 31 August 2018 / Published: 1 October 2018

\begin{abstract}
A three-dimensional two-phase non-adiabatic model is proposed for air-breathing micro direct methanol fuel cells (DMFC). The coupled heat and mass transport, along with the electrochemical reactions occurring in the air-breathing DMFC are modeled. Based on this new non-adiabatic model, the reactants distribution and concentration distribution, the pressure and flow velocity distribution, the saturation distribution, the potential and current density distribution, the temperature distribution and their effects on the cell performance are carefully examined.
\end{abstract}

Keywords: air-breathing micro direct methanol fuel cells, model, three-dimensional two-phase

\section{$\underline{\text { FULL TEXT }}$}

(C) 2018 The Authors. Published by ESG (www.electrochemsci.org). This article is an open access article distributed under the terms and conditions of the Creative Commons Attribution license (http://creativecommons.org/licenses/by/4.0/). 